\title{
Quadriplegia due to potassium depletion: A case report
}

\author{
Rachid Sirbou, Ahmed Belkouch*, Lahcen Belyamani \\ Emergency Department, Mohamed V Military Hospital of Instruction, Faculty of Medicine and pharmacy, Rabat, Morocco
}

\section{Email address:}

sirbourachid@live.fr (R. Sirbou), belkouch1@gmail.com (A. Belkouch), belyamani@gmail.com (L. Belyamani)

\section{To cite this article:}

Rachid Sirbou, Ahmed Belkouch, Lahcen Belyamani. Quadriplegia Due to Potassium Depletion: A Case Report. Science Journal of Clinical Medicine. Vol. 3, No. 6, 2014, pp. 104-105. doi: 10.11648/j.sjcm.20140306.11

\begin{abstract}
Hypokalemia is a very frequent metabolic disorder seen in emergency medicine, paralysis related to depletion hypokalemia is rare. We present the case of a 22 years old male patient who presented with flaccid quadriplegia after vomiting. After potassium supplementation the patient completely recovered. We will explain through this case the pathogenesis of this paralysis and different pitfalls that must be avoided.
\end{abstract}

Keywords: Hypokalemia, Depletion, Paralysis

\section{Introduction}

Hypokalemia is a frequent metabolic disorder, it is defined by a serum potassium level lower than $3,5 \mathrm{mmol} / \mathrm{l}$; it reaches over $20 \%$ of hospitalized patients [1]. Paralysis during this life-threatening condition is rare and is generally seen in depletion hypokalemia. The knowledge of the mechanism of this metabolic disorder is mandatory to the proper management of this kind of patients.

\section{Case Presentation}

A 22 years old male patient with a history of sarcoma of the left tibia treated surgically by amputation of the left leg and adjuvant chemotherapy, he has been admitted to the emergency department for flaccid quadriplegia, the onset was progressive since 5 days with vomiting after chemotherapy session. On clinical examination the patient was conscious, afebrile, blood pressure was $120 / 80 \mathrm{mmHg}$, heart rate $=98$ beats $/ \mathrm{min}, \mathrm{SpO} 2=95 \%$ on open air, neurological examination found a flaccid quadriplegia without sensory disorders, tendon reflexes were abolished, there was no respiratory distress and examination of cranial nerves was normal. Blood analysis showed sodium of $132 \mathrm{mmol} / \mathrm{lm}$, potassium of 1,6mmol/1, serum Bicarbonate $=28 \mathrm{mmol} / \mathrm{l}$, other biological findings were normal.

The patient was immediately transferred to the intensive care unit, ECG showed Flattened T waves; a femoral venous access was performed and potassium recharge was started using the syringe pump set at $0.25 \mathrm{mmol} / \mathrm{kg} / \mathrm{h}$, with antiemetic therapy and Proton-pump inhibitors. The heart rate was continuously monitored and serum potassium was controlled every 12 hours. Evolution was spectacular with total improvement of the quadriplegia after 24 hours of treatment. Control of serum potassium after two days was at 3,3 $\mathrm{mmol} / 1$ of and the patient was discharged.

\section{Discussion}

Hypokalemia is defined as a serum potassium level lower than $3,5 \mathrm{mmol} / 1$. This ionic disorder is frequently seen in emergency departments; it reaches over $20 \%$ of hospitalized patients [1], the severity is less than that encountered in hyperkalemia but can have major clinical consequences [2]. The occurrence of paralysis during hypokalemia depletion is rare $[3,4]$, it reaches only $3,4 \%$ of patients with hypokalemia. Muscle weakness is more common [5].

The typical clinical picture of hypokalemic paralysis can be summarized in a flaccid, ascending, symmetrical quadriplegia. It is commonly predominant at the root of the members. Tendon and idiomuscular reflexes are diminished or abolished with a lack of objective sensory disorders. [4, 6] Furthermore, although rare, diaphragmatic paralysis and cranial nerve disorders are possible $[7,8]$

The pathogenesis of paralysis due to depletion hypokalemia is explained by increasing of the $\mathrm{Ki} / \mathrm{Ke}$ ratio (intracellular potassium on extracellular potassium) [4]. The cell membrane is hyperpolarized and the cell will be more difficult to excite. These changes in membrane potential will explain the clinical electrocardiographic manifestations in this ionic disorder [9]. 
Paralysis occurs commonly when potassium depletion is fast. This could explain the lack of muscle paralysis despite deep hypokalemia below $2 \mathrm{mmol} / \mathrm{L}$, when the onset is slow and gradual [10]; Depletion hypokalemia must be differentiated from transfer hypokalemia also known as normal potassium pool hypokalemia; even if they have the same pathophysiologic consequences, therapeutic attitude differs. This kind of transfer hypokalemia within the scope of familial periodic paralysis, is characterized by an important input of $\mathrm{K}+$ into the cell by activation of the pump $\mathrm{Na} / \mathrm{K}+\mathrm{ATPase}$ stimulated by $\beta_{2}$ adrenergic agonists and thyroid hormone, also activation of the membrane exchanger $\mathrm{Na}+/ \mathrm{H}+$ stimulated by insulin increasing the intracellular concentration of $\mathrm{Na}+$, activating thereby the $\mathrm{Na}+/ \mathrm{K}+$ ATPase pump) [11].

The therapeutic approach is based on restoring hydro electrolytic and acid-base balance. The recovery of a normal nerve cell activity and even myocardial activity needs the restoring of potassium pool and prudent correction of serum potassium. A fast correction can lead indeed to myocardial electromechanical dissociation [12]. Ahead of a symptomatic deep hypokalemia, the authors [8] propose parenteral potassium intake between 0,25 to $1 \mathrm{mmol} / \mathrm{kg} / \mathrm{h}$ with hourly monitoring of the electrocardiogram and serum potassium.

The therapeutic approach should distinguish between depletion hypokalemia and hypokalemia related to a transfer of potassium which can lead to an overestimation of $\mathrm{K}+$ needs with a risk of hyperkalemia rebound when supplementing with potassium [13]. In transfer hypokalemia, it is recommended to not exceed $10 \mathrm{mmol} / \mathrm{h}$ chloride $\mathrm{K}$ and to monitor serum potassium [14].

\section{Conclusion}

Paralysis related to depletion hypokalemia is rare, potassium supplementation under cardiac rhythm monitoring and biological control leads to complete recovery of neuromuscular function, it must be differentiated from transfer hypokalemia and must always be evoked according to the context.

\section{References}

[1] H.Corraze, J.Levraut. Hypokaliemies. Journal Europeen des Urgences. 20 (2007): 86-90

[2] Groeneveld JHM, Sijpkens YWJ, Lin SH, Davids MR, Halperin ML. An approach to the patient with severe hypokalemia: the potassium quiz. Q J Med 2005;98:305-16.

[3] A. El Hijri ${ }^{*}$, M. Harandou, N. Ech-Cherif el Kettani, A. Caidi, N. Kanjaa, A. Azzouzi,, H. Benerradi, A. Slaoui. Tétraplégie secondaire à une hypokaliémie de depletion. Ann Fr Anesth Réanim $2001 ; 20$ : 294-6

[4] Mollaret P, Goulon M, Tournilhac L. Le problème des paralysies avec dyskaliémie. Presse Méd 1959; 67: 2137-8; 2225-7; 2338-40.

[5] Conn SW, Knopf RF, Nesbit RM. Clinical characteristics of pri-mary aldosteronism from analysis of 145 cases. Am J Surg $1964 ; 107: 159$

[6] Phelan DM, Worthley IG. Hypokalemic coma. Intensive Care Med $1985 ; 11: 257-8$.

[7] Christensen KS. Hypokalemic periodic paralysis secondary to renal tubular acidosis. Eur Neurol $1985 ; 24$ : 303-5.

[8] Manary MJ, Keating JP, Hirshberg GE. Quadriparesis due to potassium depletion. Crit Care Med 1986;8:750-2.

[9] A. Atikou a, M. Rabhi a,,H.Hidani b, M. El Alaoui Faris b, F. Toloune. Crise cœliaque associée à une tétraplégie par hypokaliémie de déplétion révélatrice d'une maladie cœliaque. La Revue de médecine interne 30 (2009) 516-518

[10] Mollaret P, Goulon M, Nouailhat F. Le syndrome d'hypokaliémie. Rev Prat 1965 ; 15 : 3661-72.

[11] O. Eve *, J.-L. Soubirou, L. Crevon, J.-Y. Martinez, J. Escarment Paralysie hypokaliémique révélant une hyperthyroïdie. Annales Françaises d'Anesthésie et de Réanimation 23 (2004) 745-747

[12] Nicolas G, Nicolas F, Roso L. Traitement de l'hypokaliémie. Cour Méd Interne 1976; $16: 79-82$

[13] Manoukian MA, Foote JA, Crapo LM. Clinical and metabolic features of thyrotoxic periodic paralysis in 24 episodes. Arch Intern Med 1999;159:601-6.

[14] Lin SH, Lin YF, Chen DT, Chu P, Hsu CW, Halperin ML. Laboratory tests to determine the cause of hypokalemia and paralysis. Arch Intern Med 2004;164:1561-6. 